\title{
Chapter 9 \\ Some Brief Thoughts on Housing Supply and Policy
}

Albert Saiz

\section{Introduction}

Housing markets have come to occupy a central position in the contemporaneous policy discourse of developed countries. In the past two decades, many of our cities experienced episodes of rapid home value appreciation, oftentimes accompanied by a subsequent correction. In many of the largest and most popular European citiesusually political or commercial capitals - these cyclical fluctuations cannot disguise a discernable longer run trend of substantial housing price inflation.

Raising housing prices-which may or may not imply higher user costs and lower affordability - are coming to garner substantial interest from policymakers and the public. Housing is first-order necessity, and as such commands the attention of us all.

The reasons for affordability issues in key European cities can be summarized in four major separate themes. First, increased income inequality and economic stagnation in some countries signify that the purchasing power of low-income households and the middle-class is growing slowly. This is an economic growth problem beyond and above the dynamics of housing markets (Glaeser and Gyourko 2018). Second, the productivity of the construction sector typically lags that of the economy at large. The costs of building only rise slightly faster than inflation, but are clearly growing relative to other consumer goods. Given the lackluster rates of income growth in many EU countries, this signifies that the share of household expenditures on housing for wide sections of the population may be growing (Albouy et al. 2016). Third, some of the most increasingly popular cities display relatively inelastic housing supplies and not-in-my-backyard (NIMBY) anti real estate development attitudes. Finally, a fourth set of factors relates to capital markets and an environment

\footnotetext{
A. Saiz $(\bowtie)$

Department of Urban Studies and Planning, Massachusetts Institute of Technology, Cambridge, MA, USA

e-mail: saiz@mit.edu
}

(C) The Author(s) 2019

R. Nijskens et al. (eds.), Hot Property, https://doi.org/10.1007/978-3-030-11674-3_9 
of low interest rates pushing up real estate valuations. This may not represent a problem for households with access to cheap credit-which may after all be enjoying low mortgage costs. However, it may create an insurmountable barrier for an increasing share of the population after the 2008 crisis who are unable to access credit or do not posses the substantial down payments that are now required to buy a home. In addition, a few key cities are experiencing direct foreign investment into housing, thereby further heating their markets.

In parallel to the realization that price levels are becoming unaffordable for some, there has been increasing recognition of the role of the housing market on economic fluctuations. Indeed, prominent economists have argued that "housing is the business cycle" (Leamer 2015). Consequently, housing issues have now become critical for monetary policy, as much as they are for urban planning and for national policies focusing on social welfare and cohesion.

In this short piece, I will make several considerations about the impact of housing supply on housing prices, affordability, and macroeconomic aggregates. I am focused on elucidating the key interactions between supply and demand that generate macroeconomic problems and lack of affordability. I put some emphasis on the distinction between short run and long run housing supply. My main conclusions are not new: policymakers should be aware of the Tinbergen rule. We should use multiple tools to address the multiple problems arising from housing markets. By solely focusing on one dimension we may miss big on all objectives. I will also argue that countercyclical supply-side policies are particularly damaging. I will further advocate for better data-driven mortgage underwriting models that go beyond markto-market and try to forecast future equilibrium prices. Finally, I will make an argument for a return to ambitious master-planned city building endeavors in our most expensive cities.

\section{User Cost, Demand for Dwellings, and Housing Prices}

A good starting point to understand equilibrium housing values is the simplified version of the equation in Poterba's (1984) capital asset pricing model:

$$
v_{t} P_{t}=\Delta P_{t}+R_{t}
$$

Here $P_{t}$ stands for housing prices at time $t, R_{t}$ for rents in the same period, and $v_{t}$ for the gross user cost rate of capital, excluding capital gains. The rate $v$ captures all monetary and opportunity carry costs of owning a home, expressed as a percentage of its value. This parameter includes - most saliently - mortgage costs, home maintenance expenses, tax deductions, and other more technical terms such as a factor capturing the relative cash-flow risks of owning versus renting (Sinai and Souleles 2005). The left-hand side can be interpreted as the full annual homeownership cost of carry. At any point in time, the arbitrage condition requires that the cost of ownership equals its benefits. Assuming zero mobility costs, households should 
try to ensure that they obtain housing in the cheapest way possible by either renting or owning, thereby enforcing the equality. The benefits of owning - on the right hand side-equal net real capital appreciation $\left(\Delta P_{t}\right)$ and savings from eschewing rental payments to a landlord $\left(R_{t}\right)$. In turn, long term equilibrium rental prices should be driven by the fundamental drivers of demand for the city, interacted by the long term housing supply therein.

If the temporal path of rents were known and user costs were constant, then the path of housing price growth should be fully determined in advance. It is worth restating this once again: in the absence of bubbles, all changes in housing prices should be due to either future rental growth or changes in the cost of capital. Expectations about future changes in prices should also be derived from either expected changes in rental growth or to the cost of capital. Note that Eq. (9.1) implies convexity: in environments with low initial percent user costs, the same percentage point decrease in mortgage rates is expected to increase housing demand and prices by more.

Note further that this simple model abstracts from housing quality; $v_{t} P_{t}$ here is the annuitized cost of home ownership. Cheaper capital implies lower annuitized user costs and higher housing asset demand. However, as annuitized housing ownership costs go down, it is likely for some consumers to derive part of their increased purchasing power into acquiring better housing quality. Therefore, the income effect of a low interest rate environment can manifest itself through relatively more demand-and pricing pressures—in prime neighborhoods.

\section{Capital Markets and Housing}

I have no doubt that part of the story explaining growing housing valuations in many countries was the availability of cheaper capital, as would be expected from the asset pricing formula. An abundance of global capital and low yields in the last 15 years have therefore made their way into the mortgage and real estate investment markets. The reasons for the - probably misnamed_-savings glut are many and controversial, and may include: loose monetary policies; global capital market consolidation; and the phenomenal growth of large economies with trade surpluses. Simultaneously, increasing global product competition from emerging markets has kept inflationary pressures on manufactured goods and wages at bay.

In my view, ad hoc national stories are just representations of the same global phenomenon: capital inflows or easy monetary policy allowing for low user costs and yield compression. Of course, the actors in this play are different in the different countries. It is sometimes tempting to blame the specific characters in one's own national cast of institutions for skyrocketing housing prices. For instance, in the United States some observers blamed the housing bubble of the 2000s on the ease at which subprime lenders were able to unload their toxic assets onto the securitized MBS market, under conditions of strong asymmetric information. 
While local institutions matter, I think that we can liken this situation to that of a number of different homes, all with leaky roofs. If the storm is big enough, as water (capital) comes down the roof it will eventually find its way to the basement (housing markets), but using different channels in each home; be it through the stairs, piping, siding, or down the chimney.

Capital and money abundance found a way to housing markets through securitization in the USA. In Spain, the bank channel, was the most important: the Maastricht treaty and accession to the Euro generated swift prime interest rate converge, as Spanish banks could get easy credit in safe currency from the European interbank market. Mortgage rate convergence to the core countries was abrupt. In prime markets, such as the UK and Scandinavian countries, we have seen a tightening of real estate yields and risk premia, especially after the financial crisis: capital investors - some of them local-have found it less appealing to invest in more exotic destinations. In other countries—such as Mongolia, Kazakhstan, and Azerbaijan - the housing boom and bust cycle was associated with a Dutch disease phenomenon: the increasing prices of export staples before the global crisis implied large inflows of foreign currency and growing prices of non-tradeables. In China, housing price inflation is partially driven by domestic small investors; a large share of national capital there is non-investable, controlled by state-owned enterprises. The large savings of the populace are finding their way into the housing market via direct investments in second homes. In a few global cities-London, Dubai, New York, Vancouver, Sidney, Auckland - abundant global capital has similarly found its way into the local housing market via direct purchases from foreign investors.

Nevertheless, it is important to remember that demand pressures are necessary but not sufficient conditions for price growth. Their interaction with supply is what matters in the long run (Saks 2008; Saiz 2010). A housing market with no significant barriers to entry cannot sustain continued housing price growth.

It is in this context that we sometimes confuse the problem of long-term housing unaffordability with that of bubbles or irrational exuberance. The former arises from demand fundamentals interacted with inelastic housing supply. The latter can happen even with regards to real estate assets that can be easily replicated at replacement costs, and whose value should not deviate much from such.

Incidentally, irrationalities in economic markets abound. The issue for macroeconomists is whether institutional factors negate such behavioral biases in the aggregate. For instance, irrational bubbles are less likely in markets where all information is available, salient, and common; where assets are easily tradable; short-selling is possible; with attentive participants or sophisticated arbitrageurs; small transaction or moving costs; frequent transactions for buyers and sellers to acquire experience; or mostly driven by professional investors (as opposed to retail buyers). Many of these features are missing in the housing market. Arguably, we came out of the rational expectations revolution too focused on individual rationality as opposed to the more relevant question: when and where do behavioral biases matter? 


\section{Housing Supply, Affordability, and Overheating}

I want next to hypothesize on how differences between short-term versus long-term housing supply may exacerbate the information problems that feed into behavioral mispricing and oversupply in housing markets. Consider Fig. 9.1 below. Largescale housing production requires of a long-lagged production process, entailing among others: land entitlement, zoning, planning, permitting, financing, pre-sales, infrastructure, building construction, interior finishes, utility servicing, marketing, and sales. This means that the short-run supply of housing with regards to unexpected or sudden shocks to demand is very inelastic (purple segment), because we can only rush or repurpose a few units quickly into production. As demand pressures surpass previous expectations (from D1 to D2) they may translate mostly into higher prices for some time $\left(\mathrm{P}_{\text {boom }}\right)$. Of course, no rational buyer should pay substantially more than the long run equilibrium price as justified by fundamentals $\left(\mathrm{P}^{*}\right)$ for such durable good. Nevertheless real consumers seem to be doing just that. Especially when using other people's money to do so. More vexingly, financial systems seem to underwrite long-term collateral at such short-term prices, which are not based on long run fundamentals.

Naturally, at $\mathrm{P}_{\text {boom }}$ developers want to be producing and selling as many units as financially profitable, at $\mathrm{Q}_{\mathrm{LR}}$. The issue of whether developers believe that boomtimes pricing is sustainable is only relevant to account for the speed at which they will want to unload their newly-produced stock. Globally, some of the areas that experienced the worst boom-bust cycles were those with rapid demographic growth. It is certainly possible that homebuyers and speculators there had a harder time extracting signals about how much of the parallel booms in pricing $\left(\mathrm{P}_{\text {boom }}\right)$ and new

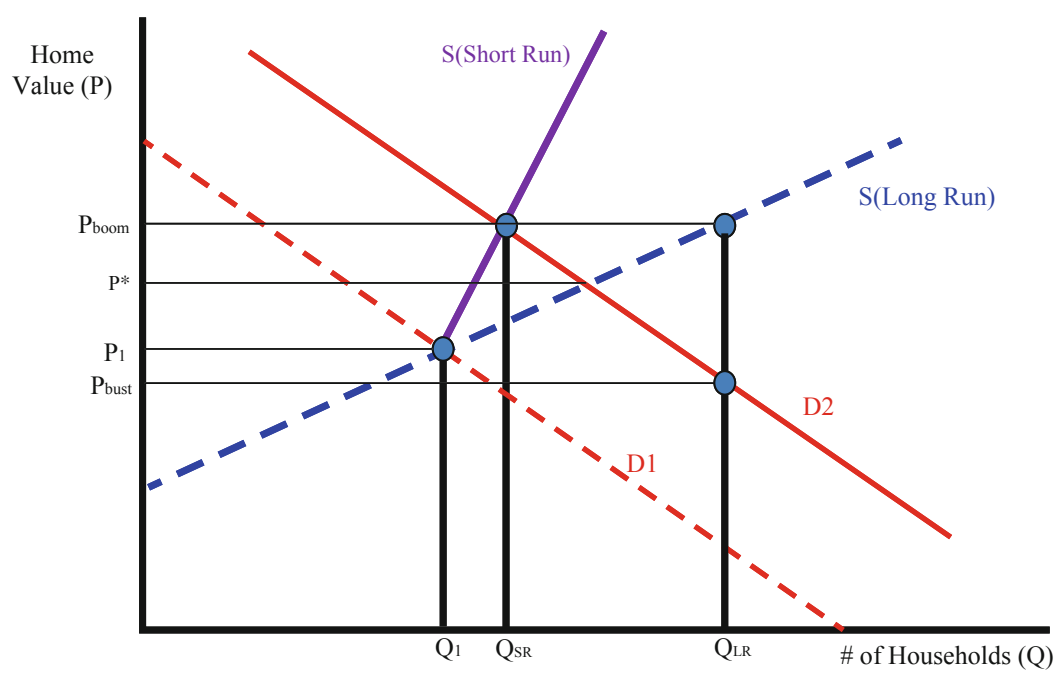

Fig. 9.1 Housing supply and demand with elastic supply 
development construction $\left(\mathrm{Q}_{\mathrm{LR}}-\mathrm{Q}_{1}\right)$ were due to fundamental growth versus exuberance.

Conversely, in areas with secularly limited household growth, it was the potential large development boom $\left(\mathrm{Q}_{\mathrm{LR}}-\mathrm{Q}_{1}\right)$ that may have seemed exuberantly unlikely to investors, thereby dampening lending and investments in new construction.

Expectations must catch up with reality eventually. At $\mathrm{P}_{\text {boom }}$ developers may have supplied up to $\mathrm{Q}_{\mathrm{LR}}$. And the new housing stock is extremely durable. Hence, the new equilibrium - back to demand expectations based on fundamentals (the ability of households to carry housing costs under reasonable appreciation paths) — should take us all the way down to $\mathrm{P}_{\text {bust }}$. Remember that housing is totally inelastic on the way down (Glaeser and Gyourko 2005).

The differences in the slope of the short term and long run housing supply could thus be behind over-construction cycles during periods with large demand shifts, like the ones prompted by decreasing user costs of housing capital.

Local observers are often astute in pointing to over-supply issues at the peak of housing boom-busts cycles. I have, unfortunately, heard arguments advocating for constraining real estate development and construction in order to avoid overbuilding cycles. In the minds of people who make such arguments, boom and bust cycles are due to the excessive "liberalization" of the housing market. In my view, this concern is misplaced. In fact, I would argue that housing supply constraints are already too tight in many large European cities. The temptation to restrict supply in order to prevent overbuilding will exacerbate long-term affordability problems in the most successful cities.

Consider Fig. 9.2 below, applying to city with a much more inelastic housing supply. Here, because the long run supply schedule is already very steep, the

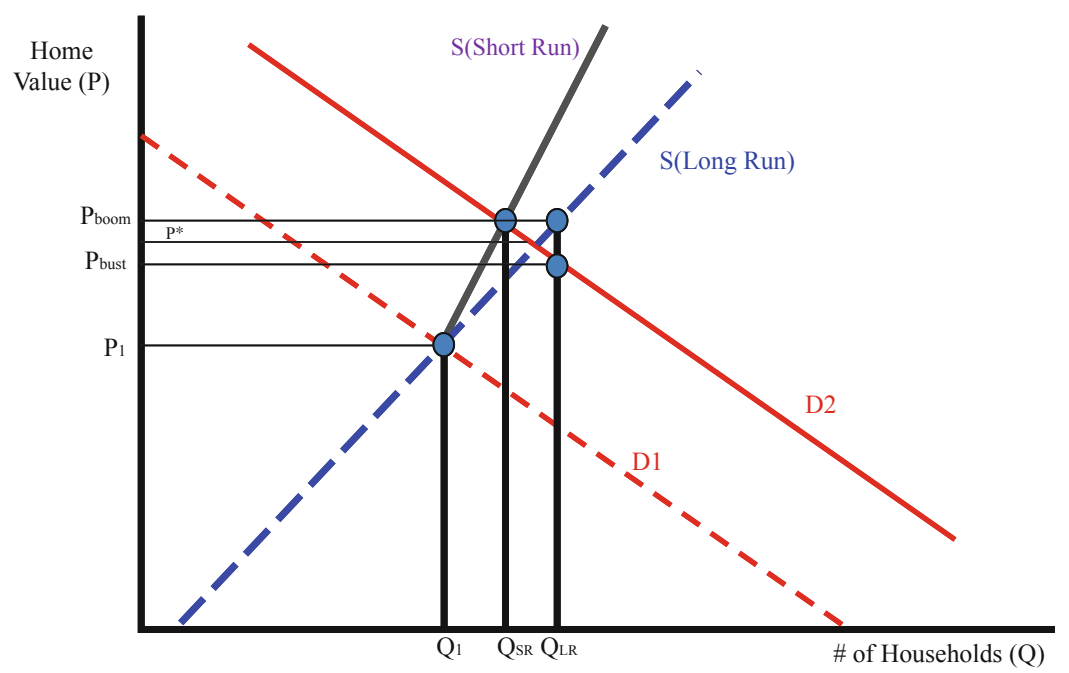

Fig. 9.2 Housing supply and demand with inelastic supply 
differences between short term and long term supply are not as large. There is less over-construction and the boom-bust price difference is small. Anti-supply policies can indeed retard development and reduce the gap between long term and short-term construction. However, this would be a pyrrhic victory: the housing market has now become very unaffordable, a much worse problem for most citizens.

The main problem with using constraining supply-side policies countercyclically is that regulators do not know the nature of the shocks that are hitting the housing market, and may therefore confuse irrational overbuilding with fundamental demand pressures.

Policymakers have more than one objective with regards to housing markets. They should therefore heed Tinbergen's rule, and use a different policy instrument to attain each objective. It is problematic to use the same policy instrument-e.g. constraints on credit expansion - to combat both housing unaffordability and irrational market overheating or overbuilding.

For two potential problems we need at least two separate policy instruments. It is probably best to use demand-side instruments to fight against market overheating. The set of existing tools here typically revolves around setting more conservative underwriting standards-lower Loan-To-Value (LTV) ratios, more stringent household income validation, higher mortgage rates. These instruments have been somewhat effective in the past. However, we should hope for better ones in the future.

\section{Mortgage Underwriting Using Fundamental Housing Valuation Forecasts (FHVF)}

A potential idea is for banks to underwrite mortgages using forecasted expected equilibrium prices, rather than current mark-to-market valuations. Going back to Fig. 9.1, it is really strange to see financial institutions underwriting long-term credit at $\mathrm{P}_{\text {boom }}$, even in markets where the supply elasticity is very high and a new building can be eventually begotten at construction cost plus a modest land outlay. Underwriting based on current market transaction prices is mandatory in many countries, so laws and banking regulations will need to change. More stringent capital ratios should be applied to any mortgage lending that goes above and beyond a maximum percentage of FHVFs.

Imagine-hypothetically and going back to seventeenth Century Netherlandsthat the authorities had required banks and wealthy merchants to extend credit for up to $90 \%$ of the market value of tulip bulb contracts to anyone buying them. Such policy would have likely exacerbated the tulip mania of 1636-1637. But regardless of the extent of its general equilibrium impact on prices, the policy would have certainly forced the collapse of more lending institutions. Inducing creditors to lend at collateral valuations that are potentially determined by a bubble does not make much sense. But many housing finance policies and institutions around the world are doing just that! 
I propose that financial institutions or central banks use data from past urban growth and housing values in each city, plus other urban characteristics-extent of restrictive planning, green belts, geographic constraints, urban structure, rental gradients within cities - in order to estimate local housing supply elasticity schedules. One could then come up with estimates of housing demand shocks-e.g. the impact of changes in user costs on demand, or demographic growth-in order to forecast long run equilibrium prices. To reiterate, it makes sense for institutions that have a long-term stake on an asset to estimate alternative valuation scenarios at 5, 10, 15 year maturities, and so on. Nowadays, professional assessments or automated valuation models (AVM) simply estimate what people are paying right now for similar properties. Even simple FHVF time series models with mean reversion to an equilibrium price are likely to do better than AVMs to assess long-term credit risk.

Publically traded futures or over-the-counter forward contracts based on metropolitan price indexes-which could attract sophisticated analytical players-have achieved so far limited reach. Therefore, central banks may be well positioned to offer FHVF models for several of the largest metropolitan areas at different future maturities, as a public good to the banking system.

Allowing for underwriting standards that mark to FHVFs would feature positive automatic stabilizer qualities. Consider a thought experiment with two cities: A and B. Housing supply in A is very inelastic, whereas it is very elastic in B. Both cities feature the same demand shock, perhaps due to lower mortgage rates. However, both cities have experienced similar rapid housing price appreciation, with home values doubling. It is possible - though uncertain - that city A's housing market is overheated. But it is very clear that housing prices in B should have grown much less than in A. With good estimates of the elasticities of demand and local supply, the central bank can come up with a forecast that predicts lower long-term equilibrium prices at B. Banks therefore underwrite their 30-year mortgage credit using lower long-run valuations there. Mark-to-market LTVs at B automatically decrease, making it hard for people to pay exuberant prices. In equilibrium, this dampens demand pressures until prices at B moderate to, approximately, their fundamental values.

Note that applying FHVF underwriting standards is not tantamount to the banks setting housing prices themselves. Consumers can always decide to pledge more funds toward paying for any market price they want to buy at, however farfetched. FHVF underwriting just prevents them from using other people's money to do so.

Without a doubt, it is very difficult for politicians to pass measures that seem to restrict access to credit, even if banks are now underwriting rationally and countercyclically. As the boom frenzy feeds the housing market in city B above-and until credit constraints dampen prices-some households may be unable to afford the required down payments. They will typically be young and less well off.

Nevertheless, politicians should be aware of the general equilibrium implications of letting credit standards blindly follow after housing price growth. By providing powerful weapons - credit - to all customers, they are effectively putting them in a circular firing squad: it may be precisely the generalized availability of credit that reinforces the problem of over-pricing, fueling the bubble and exacerbating 
unaffordability. With a substantial share of credit-constrained households-in theory-mortgage underwriting that marks to long-term fundamental valuations should impede for bubbles to arise in the first place.

\section{Make Supply Elastic Again}

Going back to the Tinbergen rule, long-term affordability issues need separate policy tools than those applied to overheating. Supply side interventions are the optimal candidates here. Generally speaking, policymakers may want to make both long and short term housing supply as elastic as possible.

There remain substantial barriers to construction and densification in many of the more attractive European cities. These areas are experiencing growing demand due to the consumer city phenomenon (Glaeser and Gyourko 2018; Carlino and Saiz 2008). European countries may have been expected to experience lackluster housing demand expansion. Most countries do not display strong demographic growth; the process of reduction in household sizes seems to have reached a limit (remember that: total number of homes demanded $=$ population $\times$ [homes/person]); the positive income elasticity of space could perhaps be decreasing due to cultural changes that emphasize compact-city, green living. However, the competition between cities to attract talent and provide an improved lifestyle has unambiguously grown. Excepting for immigrant arrivals, the main driver of real estate development in European cities is therefore the redistribution of national demand towards the most attractive cities.

Of course, this implies symmetrical negative pressures on second and third tier cities and markets, which may experience decline. This phenomenon may translate into political pressures for national governments to enact anti-development regulations or to discriminate against the most successful cities. These turn to be counterproductive, rendering successful cities even more expensive and pricing out their working classes, without avoiding the exodus of entrepreneurs and the highly skilled from lower-tier areas. More strategically, anti large city policies may be really missing the point: do Europeans want to have global cities that are able to hold their own in the worldwide competition for talent and employers, or not?

I have discussed innovative supply-based strategies to provide affordable housing elsewhere (Saiz and Salazar 2017). Some of the ideas include: adaptive reuse; residential development in post-industrial cities; inclusionary upzoning; densification; infill; suburban master-planned communities; micro-units; accessory units; co-living; sweat equity in construction; building cooperatives; mixed for/non-profit developments; negotiations with unions; use of prefab materials and technology in construction; and the development of flexible rental market institutions.

Notwithstanding any potential innovations, NIMBY opposition to real estate development will keep on being a major issue in Europe, as it is in the United States. 
But, in fairness, many isolated housing development projects do not provide much to current homeowners in terms of aesthetics, urbanistic externalities, amenities and services, or civic virtue. As Saiz and Salazar (2017) write:

Reducing NIMBY pressures in the suburbs requires building coalitions and garnering some support from local communities. This can be done by offering a positive holistic vision for development. In some cases this underscores the need for large master-planned neighborhoods that offer plenty of amenities to be enjoyed by all in town. The execution of suburban development master plans can add value to existing residents' lives by delivering mixed-use, walkable town centers that provide amenities such as parks, promenades, playgrounds, and restaurants. These large-scale, multi-period developments can also anchor civic activitiesfestivals, farmers' markets—or integrate and centralize public buildings—senior centers, libraries - in a convenient and enjoyable location. Existing residents may be even more likely to support such plans if they bring permanent local jobs, have well-designed positive impacts on local education systems, and replace previously developed sites that were eyesores.

I would like to exhort European civic leaders to think big again, and create templates for massive, new, mixed-used developments within our most expensive metropolitan areas. These should include plans for tens of thousands of marketsupplied new residential units. By frontloading most the planning and approvals processes within these special zoning areas, developers can flexibly phase in or out construction: stopping when markets slow down; quickly responding to increasing demand. Our leaders should inspire the public to get deeply involved in improving the quality of new development, eschewing counterproductive obsessions about its quantity. The scale of the new megacities cities now arising in the developing world-China, Saudi Arabia, Korea-is unlikely to be suitable to the European situation. Yet citizens in super-expensive metros do need inspiring projects that pass market muster, are self-financing, have net positive environmental impact, help resolve affordability problems, and allow them to dream big. It is incumbent among our political leaders to thus drive the renewal of our collective ambitions into such economically productive endeavors.

\section{References}

Albouy, D., Ehrlich, G., \& Liu, Y. (2016). Housing demand, cost-of-living inequality, and the affordability crisis (National Bureau of Economic Research Working Paper No. w22816).

Carlino, G. A., \& Saiz, A. (2008). Beautiful city: Leisure amenities and urban growth (FRB of Philadelphia Working Paper No. 08-22).

Glaeser, E. L., \& Gyourko, J. (2005). Urban decline and durable housing. Journal of Political Economy, 113(2), 345-375.

Glaeser, E., \& Gyourko, J. (2018). The economic implications of housing supply. Journal of Economic Perspectives, 32(1), 3-30.

Leamer, E. (2015). Housing really is the business cycle: What survives the lessons of 2008-2009? Journal of Money, Credit and Banking, 47(S1), 43-50.

Poterba, J. M. (1984). Tax subsidies to owner-occupied housing: An asset-market approach. The Quarterly Journal of Economics, 99(4), 729-752. 
Saiz, A. (2010). The geographic determinants of housing supply. The Quarterly Journal of Economics, 125(3), 1253-1296.

Saiz, A., \& Salazar, A. (2017). Real trends: The future of real estate in the united states (SSRN Working Paper 3100934).

Saks, R. E. (2008). Job creation and housing construction: Constraints on metropolitan area employment growth. Journal of Urban Economics, 64(1), 178-195.

Sinai, T., \& Souleles, N. S. (2005). Owner-occupied housing as a hedge against rent risk. The Quarterly Journal of Economics, 120(2), 763-789.

Open Access This chapter is licensed under the terms of the Creative Commons Attribution 4.0 International License (http://creativecommons.org/licenses/by/4.0/), which permits use, sharing, adaptation, distribution and reproduction in any medium or format, as long as you give appropriate credit to the original author(s) and the source, provide a link to the Creative Commons licence and indicate if changes were made.

The images or other third party material in this chapter are included in the chapter's Creative Commons licence, unless indicated otherwise in a credit line to the material. If material is not included in the chapter's Creative Commons licence and your intended use is not permitted by statutory regulation or exceeds the permitted use, you will need to obtain permission directly from the copyright holder. 